\title{
Motivation and Gender Effect in Receptive Vocabulary Learning: An Exploratory Analysis in CLIL Primary Education ${ }^{1}$
}

\author{
Motivación y género en el aprendizaje del vocabulario receptivo: \\ un análisis exploratorio en educación primaria AICLE \\ Almudena FernandeZ-FonteCha \\ Universidad de La Rioja \\ (La Rioja, Spain)
}

\begin{abstract}
The present paper seeks to address the connection between the receptive vocabulary size and motivation towards EFL of a group of CLIL primary graders by paying special attention to learners' gender variation. In particular, our goal is to probe into (1) gender variation in EFL receptive vocabulary size, (2) gender variation in motivation towards the foreign language, and (3) the relationship between motivation towards the foreign language and scores in a receptive vocabulary test. No statistically significant differences are found on gender variation neither in EFL receptive vocabulary size nor in motivation, both boys and girls follow quite similar patterns; finally, we have identified a positive correlation between boys' levels of intrinsic motivation and the number of words they know receptively. The waning effect of CLIL on gender variation, as shown in previous research, is adduced here as one of the possible sources of lack of differences both in vocabulary achievement and motivation.
\end{abstract}

Key Words: Motivation; receptive vocabulary size; gender; content and language integrated learning (CLIL); English as a foreign language (EFL).

\section{Resumen}

En el presente artículo se explora la relación entre el tamaño de vocabulario receptivo y la motivación hacia el inglés como lengua extranjera de un grupo de alumnos AICLE de educación primaria prestando una especial atención a la variación de los resultados según el género de los alumnos. En particular, el objetivo de este estudio es analizar (1) la variación según la variable género de la motivación de los alumnos en el tamaño de vocabulario receptivo, (2) la variación según el género de los alumnos de su motivación hacia la lengua extranjera la lengua extranjera y (3) la relación entre la motivación hacia la lengua extranjera y el tamaño de vocabulario receptivo. No se aprecian diferencias estadísticamente significativas en la variación según la variable género ni en el tamaño de vocabulario receptivo ni en la motivación. Tanto chicos como chicas siguen patrones similares. Sin embargo se ha identificado una correlación positiva entre los niveles de motivación intrínseca de los chicos y el número de palabras que conocen de manera receptiva. Como se ha demostrado en investigaciones previas, se apunta al efecto atenuador de AICLE en la variación de género como una de las posibles razones de esta falta de diferencias en la adquisición de vocabulario y la motivación.

Palabras Claves: motivación; tamaño de vocabulario receptivo; género; aprendizaje integrado de contenidos y lengua extranjera (AICLE); inglés como lengua extranjera (ILE).

\footnotetext{
${ }^{1}$ This study is part of the research project "Factores individuales y contextuales en la adquisicion $y$ desarrollo de la competencia léxica en inglés como lengua extranjera" funded by the Spanish Ministerio de Ciencia e Innovación (Grant Ref. No: FFI2010-19334/FILO).
} 


\section{INTRODUCTION}

Grounded in the Canadian immersion, content and language integrated learning (CLIL) has become a central approach to foreign language learning and teaching in the last twenty years in Europe. CLIL is considered an umbrella term that allows for a myriad of educational practices from those more content-oriented to those more language-oriented. Research on CLIL is abundant and varied. For example, the influence of CLIL in the different language skills and components in across different educational levels and classroom situations has received extensive attention (for example, Dalton-Puffer \& Smit, 2007; Ruiz de Zarobe \& Jiménez Catalán 2009; Dalton-Puffer, Nikula, \& Smit 2010; Llinares, Morton, \& Whittaker 2012; Fortanet-Gómez 2013). Motivation is considered a driving force for this type of instruction, as one of the strongest pillars of CLIL is to engage learners in meaningful ways of using the language with a given purpose. The aim of this study is to shed light on the interaction between the receptive vocabulary size and motivation towards English as a foreign language (EFL) of a group of CLIL primary graders. The gender variable is particularly explored in this study. Following, we will review the evidence for these topics found in recent literature.

\section{Individual and contextual factors: motivation, gender and CLIL}

Motivation has become a central issue within the field of foreign language learning (Lasagabaster, 2003; Dörnyei \& Ushioda 2009; Anglada \& Banegas 2012; Gabryś-Barker \& Bielska, 2013). Many are the models on motivation found in the literature. The Socio-Psychological model by Gardner and Lambert (1972) was a pioneer in the field. In subsequent years, other models have deserved attention, such as the Self-Determination Theory (Deci \& Ryan, 1985; Noels, Pelletier, Clément, \& Vallerand, 2000) or more recently the L2 Motivational Self System (Dörnyei 2005; 2009). In different models, the dichotomy between inner and outer reasons for learning languages is relevant. In Gardner and Lambert's model, motivation towards the learning of a language is understood as the desire to command the language through effort, want, affect or attitude. The terms integrative and instrumental orientation address this double face of motivation. Whilst integrative orientation is construed as the ultimate goal behind learning a foreign language, instrumental orientation is taken to mean the desire to control the foreign language for external reasons. In Self-Determination Theory, external 
factors are covered by extrinsic motivation and internal factors are included in the term intrinsic motivation. However, a deep study of each model would shed light on the differences between each set of terms. Whatever model is used, a positive correlation is generally observed between motivation and foreign language learning, as a considerable amount of research has consistently shown (for example, Schmidt \& Watanabe, 2001; Masgoret \& Gardner, 2003; Csizér \& Dörnyei, 2005; Bernaus \& Gardner, 2008; Yu \& Watkins, 2008).

In motivation studies it is also frequent to tackle the relationship of motivation with other variables, such as gender or age. The variable of gender, for instance, has been widely studied in motivation research. Overall, statistically significant variation that shows higher levels of motivation in girls is identified in a substantial body of studies (for example, Sung \& Padilla, 1998; Dörnyei \& Csizér, 2002; Mori \& Gobel, 2006; Henry \& Apelgren, 2008; Dabbagh \& Khajehpour, 2011; Henry 2012). Exceptions are also noted, such as by Azarnoosh and Birjandi (2012), who identified no differences between attitudinal factors towards the foreign language of male and female junior high school students. The female advantage is also extended to types of motivation since there is ample conclusive evidence that girls are more integratively and instrumentally motivated than boys (for example, Dörnyei \& Clement, 2001; Dörnyei \& Csizér, 2002; Dörnyei, Csizér, \& Németh 2006).

Situational factors are also agreed to shape language learners' motivation. Through cognitively rich activities, for example, CLIL pedagogies attempt to provide language learning with a meaningful context that is missing in traditional EFL instruction. The philosophy behind CLIL suggests that motivation is likely to increase as a result of this new mode of instruction, and this growth would presumably affect positively learners' language achievement. Thus, learners' motivation becomes an implicit element in CLIL, as postulated in CLIL handbooks (Mehisto, Marsh \& Frigols, 2008; Coyle, Hood, \& Marsh, 2010). Some critical voices have already argued against the important empirical gap that concerns the interaction between motivation and CLIL (Bruton, 2011, as cited by Cenoz, Genesee, \& Gorter, 2013, p. 14). In general, research has focused on analysing the interaction between motivation and language achievement. For example, Lasagabaster (2011) finds higher levels for CLIL learners in different types of motivation, in their attitudes towards EFL, effort and in their grammar results. Also Huang (2011) identifies an improvement in motivation and in the 
academic performance of a group of 25 primary learners in Taiwan. Learners participated more actively in content classes than in language classes and they were more eager to volunteer and classroom verbal output. Further studies, such as Murtagh (2007) or Seikkula-Leino (2007), also conclude that there exists a positive connection between language learning and motivation.

In any case, in the interpretation of motivation results, issues that remain relatively under-researched should be covered. Among them, we should note the ideas that in many cases the CLIL students are already motivated towards the foreign language before they enroll to this type of instruction or that the requirement of using a language unknown to the learner might cause a decrease in motivation as a result of a loss of self-esteem (Cenoz, Genesee, \& Gorter 2013, p. 14-15). An example of this is highlighted in a study by Mearns (2012), who found higher levels of motivation towards German as a foreign language of a group of CLIL secondary graders but, on the other hand, that "speaking in front of the class" activities affected their levels of confidence. The most able students exceeded their previous results, but little improvement was perceived in the less able pupils. As Doiz, Lasagabaster, and Sierra (in press) note, although CLIL students prove to be more motivated than non-CLIL students, this type of result should be analysed with caution since contextual variables and individual variables, such as age and sex, might be having some effect on the results.

Some studies have also reported some results about the confluence of motivation and gender in CLIL settings. In the Canadian immersion context, a line of research studies identifies some sort of weakening of gender variation in language achievement, which favours males' achievement and motivation (Baker and MacIntyre 2000). The same waning effect is identified by Merisuo-Storm (2007) in an investigation with primary education students in Finland. By contrast, Lasagabaster and Sierra (2009) concluded that in weaker versions of CLIL, this effect is not perceived and an overall girls' superiority is identified, following the tendency in research on motivation and language learning in nonCLIL settings.

\section{L2 receptive vocabulary knowledge}

L2 vocabulary learning is a major topic within the field of applied linguistics. Studies in this particular area distinguish between productive and receptive 
vocabulary knowledge (for example, Schmitt, 2000; Qian, 2002; López Mezquita, 2005; Nation, 2006). While the former is related to the production of words in order to match speakers' intention both in writing and speaking, the latter addresses the perception of words and meaning comprehension in listening and reading (Nation, 2001). Receptive vocabulary size-that is, the number of words that learners know-often correlates with proficiency, exposure to the language, and also frequency of vocabulary input (Fan 2000; Golberg, Paradis, \& Crago, 2008). Some of these features can be identified in CLIL since it provides repeated exposure to new vocabulary and contextualization, as Xanthou (2010) notes.

The effect of motivation on vocabulary learning has often been left unexplored in the literature. Few studies have paid attention to this relationship. Laufer and Hulstijn (2001) discuss the Involvement Load Hypothesis, which refers to the cognitive and motivational weight of vocabulary tasks. Based on this hypothesis, Kim (2008) concludes that there is a connection between motivation and lexical performance; a meta-analysis conducted by Huang, Eslami, and Wilson (2012) confirms this finding. For example, these authors found that language learners who completed an output task outperformed those who only read a text, and language learners who performed a task with a higher degree of involvement load gained more vocabulary. In a longitudinal study, Zheng (2012) makes use of Dörnyei's (2005) L2 Motivational Self System, to identify a very complex interplay between learners' fluctuating motivational levels and productive vocabulary development. Along the same lines, Tseng and Schmitt (2008) probe into vocabulary knowledge and motivation and suggest that motivated vocabulary learning follows a developmental mode and functions as a cyclic process as learners' motivation towards vocabulary learning ebbs and flows over a period of time.

In interpreting how motivation affects vocabulary acquisition, the productive-receptive types of vocabulary should be particularly addressed. An issue that could be affecting motivation is that vocabulary production is a more demanding task than vocabulary reception, as Laufer and Paribakht (1998) point out. Nation (2001, p. 28) reinforces this aspect by suggesting that we need to have a sense of wanting to convey a message, something which is missing in receptive vocabulary tasks.

So far, however, there have been fewer studies that combine L2 vocabulary achievement together with gender and motivation in a CLIL setting. With utmost 
caution, as CLIL is implemented under different conditions, research has shown that CLIL favours receptive and productive types of vocabulary, the learning of more low frequency words and more varied stylistic range, as Dalton-Puffer (2011, p. 186) notes. Fernández-Fontecha (2010b) detects that females' show higher levels of motivation and that these levels correlate positively with their achievement in a productive vocabulary task. In this study, intrinsic and extrinsic types of motivation have a strong effect on girls' production of L2 vocabulary. A more recent study by Heras and Lasagabaster (in press) concludes that CLIL reduces gender variation in motivation and that achievement in technical content-related vocabulary results benefited from CLIL both for male and female secondary education students.

Having highlighted the double paucity of research-first, on individual variables that interact with motivation in CLIL, and second, with regards to the effect of motivational factors in vocabulary learning - the present paper explores the relationship between motivation and L2 vocabulary learning in a CLIL setting by probing into the study of (1) gender variation in EFL receptive vocabulary size, (2) gender variation in motivation towards the foreign language, and (3) the relationship between motivation towards the foreign language and scores in a receptive vocabulary test.

\section{METHODOLOGY}

\section{Participants}

The participants of this study were a group of 55 Spanish-speaking EFL learners in the fifth grade of primary education. This group consisted of 30 boys and 25 girls, aged around 10-11 years old. They all belonged to a school centre located in La Rioja, in the north of Spain, and were enrolled in a CLIL programme called PILC-B (Proyectos de Innovación Lingüística en Centros/School Language Innovation Projects). In type B of this programme, a subject or part of a subject is taught in the foreign language by content teachers (Fernández-Fontecha, 2010a). The type of CLIL implementation can be considered a weak one. At the time of data collection, these students had received approximately 839 hours of instruction in EFL. They had been exposed to 524 hours of English as the object of instruction, and they had also received 315 extra hours of CLIL English 
through Natural Sciences. Textbooks and other materials written in English were used in the CLIL classes.

\section{Data gathering instrument, procedures and analysis}

As a data collection instrument to measure learners' receptive vocabulary size, we used Schmitt, Schmitt and Clapham's (2001) version 2 of the 2,000-word frequency-band from the receptive version of the Vocabulary Levels Test $(2 \mathrm{~K}$ VLT) (Appendix 1). This test covers 10 groups of 6 words, with 3 definitions per group. The test-takers must match each target word to its corresponding definition. The maximum score is 30 points; correct matching is given 1 point. The test-takers had 10 minutes to complete the test. In order to calculate the students' word we applied the following formula developed by Nation (1990, p.78): Vocabulary size $=\mathrm{N}$ correct answers multiplied by total $\mathrm{N}$ words in dictionary (the relevant word list) divided by $\mathrm{N}$ items in test. The VLT test has been extensively used and validated in research (Agustín Llach \& Terrazas Gallego, 2012; Mokhtar et al., 2010; Cameron, 2002; Schmitt, Schmitt, \& Clapham, 2001; Laufer \& Paribakht, 1998; Schmitt \& Meara, 1997; Read, 1988). With a worddefinition matching format, it assesses receptive vocabulary size or breadth based on the subjects' recognition of words of graded frequency lists of 2,000,3,000, and 5,000 words, the Academic Word List, and the 10,000 most frequent words in English. Knowing words in a frequency band implies knowing words in all lower bands. In general, VLT studies conclude that the L2 proficiency level or the time of exposure to the foreign language affects the number of words learners know receptively.

In order to assess general, intrinsic and extrinsic motivation, we made use of a questionnaire adapted from Gardner's (1985) Attitude/Motivation Test Battery (A/MTB) (Appendix 2). It consists of a semantic differential technique of 7-point bipolar rating Likert scale using the following 7 pairs of bipolar adjectives: 'necessary'/'unnecessary', 'ugly'/'nice', 'attractive /'unattractive', 'pleasant'/'unpleasant', 'important'/'unimportant', 'useful'/'useless', and 'interesting'/'boring'. These adjectives are introduced with the Spanish phrase "Considero que el inglés es ..." ("I consider English to be ..."). Intrinsic motivation is measured through the pairs 'ugly'/'nice', 'attractive'/'unattractive', 'pleasant'/'unpleasant', and 'interesting'/'boring'; extrinsic motivation is 
measured through the pairs 'necessary'/'unnecessary', 'important'/'unimportant', and 'useful'/'useless'. The pair 'difficult'/'easy' is also included as a kind of distractor since it does not measure motivation. General motivation is tested through the 7 pairs of adjectives. It is important to note here that in this study we make use of a simplified version of intrinsic and extrinsic motivation; that is, one in which intrinsic motivation is defined by learners' opinions on endogenous factors of EFL and extrinsic motivation refers to exogenous factors of learning a foreign language. Other aspects related to motivation are not considered here.

Finally, we coded data from the VLT and the motivation scale and analysed them through SPSS (Statistical Package for Social Sciences) (version 19.0).

\section{RESULTS}

\section{Gender variation in EFL receptive vocabulary size.}

As Table 1 shows, the patterns for boys and girls are quite similar, with a slight advantage in favour of boys. The maximum score in the $2 \mathrm{~K}$ VLT is 30 points. The boys' mean was 10.93 and girls' was 10.16. However, these differences are not statistically significant: $t(53)=0.704, p=0.773$. Higher standard deviation was identified in the case of girls (4.30 vs. 3.84). Minimum and maximum results were almost the same in both cases.

Table 1. 2K VLT: Descriptive statistics

\begin{tabular}{lllll}
\hline Groups & Min. & Max. & Mean & SD \\
\hline All & 1 & 19 & 10.58 & 4.04 \\
Boys $(\mathbf{n = 3 0 )}$ & 1 & 19 & 10.93 & 3.84 \\
Girls $(\mathbf{n = 2 5})$ & 2 & 19 & 10.16 & 4.30 \\
\hline
\end{tabular}

In Table 2, we present the results from both groups after applying Nation's (1990, p. 78) formula: Vocabulary size $=\mathrm{N}$ correct answers multiplied by total $\mathrm{N}$ words in dictionary (the relevant word list) divided by $\mathrm{N}$ items in test. Thus, we perceive that no group reaches a mean word estimate of 1,000 words: boys know 728 words, and girls know 677 words. 
Table 2. Word estimates

\begin{tabular}{lllll}
\hline Groups & Min. & Max. & Mean & SD \\
\hline All & 67 & 1267 & 705 & 269 \\
Boys $(\mathbf{n = 3 0 )}$ & 67 & 1267 & 728 & 256 \\
Girls $(\mathbf{n = 2 5})$ & 133 & 1267 & 677 & 287 \\
\hline
\end{tabular}

\section{Gender variation in motivation towards the foreign language.}

In these results, we make use the following acronyms: GMot (general motivation), IMot (intrinsic motivation), and EMot (extrinsic motivation). We wanted to identify how motivated (GMot), how intrinsically motivated (IMot), and how extrinsically motivated (EMot) our learners were. As can be seen from Table 3, the results in motivation are quite similar in all cases in both groups. Boys and girls' means of motivation (general and types) are around 5 and 6 . In the test of motivation we applied, 7 is the highest result. Girls score slightly higher with regards to GMot and IMot, but boys surpass them in EMot. However, these differences are not statistically significant: GMot: $t(53)=0.080, p=0.937$; IMot: $\mathrm{t}(52)=-0.593, \mathrm{p}=0.556$; and EMot: $\mathrm{t}(53)=1.068, \mathrm{p}=0.291$. We note a high homogeneity in these results as low standard deviation (SD) is identified in all cases. Greater standard deviation is found in the case of girls' GMot and IMot (Figure 1).

Table 3.Motivation: Descriptive statistics

\begin{tabular}{llllll}
\hline Gender & Motivation & Mean & Max. & Min. & SD \\
\hline Boys (n=30) & GMot & 5.91 & 7 & 4.14 & 0.78 \\
& IMot & 5.31 & 7 & 3 & 0.99 \\
& EMot & 6.66 & 7 & 5 & 0.61 \\
\multirow{3}{*}{ Girls (n=25) } & GMot & 5.89 & 7 & 3.86 & 0.98 \\
& IMot & 5.50 & 7 & 3 & 1.32 \\
& EMot & 6.45 & 7 & 3.67 & 0.86 \\
\hline
\end{tabular}

In addition to identifying mean values of motivation, we wanted to know how the learners were distributed across the different levels of general motivation. For 
that purpose, we established three levels of mean general motivation. Level 1 covers low motivation marks (that is, 1.0-3.0) level 2 comprises medium motivation marks (that is, 3.01--5.0), and level 3 includes high motivation marks, (that is, 5.01-7.0). Table 5 displays the results across these levels by gender. The patterns obtained are very similar. No girl or boy obtained low motivation marks.

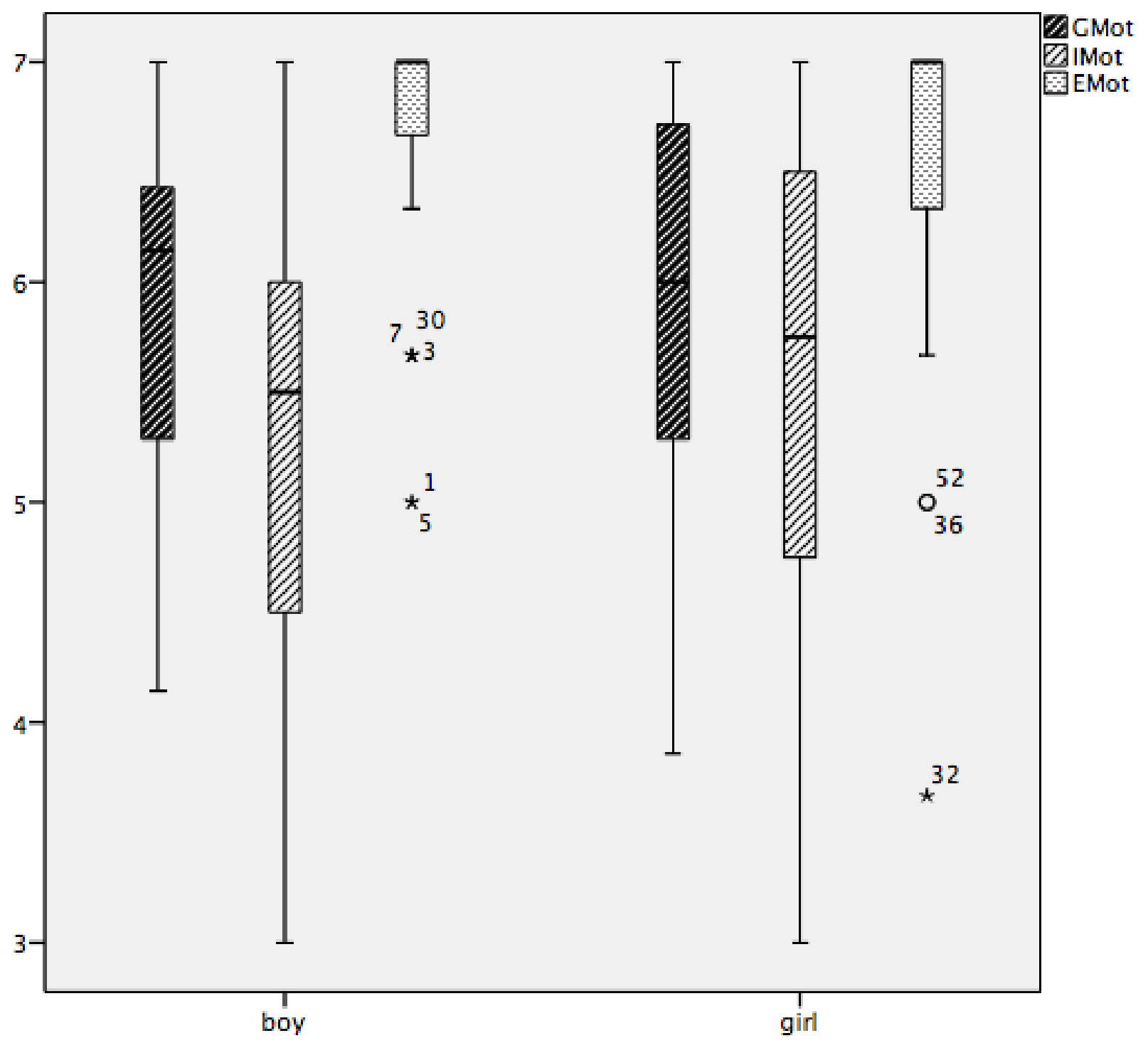

Figure 1. Motivation: Males and females' median values

Table 4. Levels of GMot: number and percentage of learners

\begin{tabular}{ccc}
\hline GMot & Level 2 \\
\hline & $\begin{array}{c}\text { Level 3 } \\
\text { An exploratory analysis in CLIL primary education. Latin American Journal of Content and } \\
\text { Language Integrated Learning, }\end{array}$ \\
\hline
\end{tabular}




\begin{tabular}{llll}
\hline Boys $(\mathbf{n = 3 0})$ & N & 4 & 26 \\
& $\%$ & 13 & 86 \\
Girls $(\mathbf{n}=\mathbf{2 5})$ & N & 5 & 20 \\
& $\%$ & 20 & 80 \\
\hline
\end{tabular}

We also identified a statistically significant correlation between both types of motivation, intrinsic and extrinsic, in boys and girls, as displayed in Table 5.

Table 5.Correlation between IMot and EMot per sex

\begin{tabular}{llll}
\hline & & IMot & \\
& & $\boldsymbol{r}$ & $\boldsymbol{p}$ \\
\hline Males & EMot & $.639^{* *}$ & .000 \\
Females & Emot & $.468^{*}$ & .024 \\
\hline
\end{tabular}

** Correlation is significant at the 0.01 level.

${ }^{*}$ Correlation is significant at the 0.05 level

Relationship between motivation towards the foreign language and scores in a receptive vocabulary test.

We used Pearson's correlation coefficient to measure this relationship. As can be seen from Table 6, only in the case of boys the correlation between the $2 \mathrm{~K}$ VLT and GMot $(\mathrm{r}(30)=0.497, \mathrm{p}=0.005)$ and $2 \mathrm{~K}$ VLT and IMot $(\mathrm{r}(25)=0.487), \mathrm{p}=$ 0.007 ) is statistically significant. As for $2 \mathrm{~K}$ VLT and EMot, the correlation is not statistically significant in any case.

Table 6. Correlation between motivation and $2 \mathrm{~K}$ VLT

\begin{tabular}{llll}
\hline & & \multicolumn{2}{c}{$2 \mathrm{~K}$ VLT } \\
\hline Males & Gmot & $.497^{* *}$ & $p$ \\
& Imot & $.487^{* *}$ & .005 \\
& Emot & .256 & .007 \\
\hline Females & Gmot & .025 & .172 \\
& Imot & -.002 & .906 \\
& Emot & .051 & .993 \\
\hline
\end{tabular}

** Correlation is significant at the 0.01 level. 


\section{DISCUSSION}

The first research question of this study asks whether there were any gender differences in the size of EFL receptive vocabulary of learners. The results obtained show that, although males are slightly more motivated, both boys and girls follow similar patterns, although this variation is not statistically significant. This result is consistent with inconclusive results in previous research on gender variation in receptive tasks (Agustín \& Terrazas, 2012).

Another point worth mentioning here is that, with 839 hours of exposure to English as a foreign language, neither boys nor girls reach a mean word estimate of 1,000 words. This figure is considerably lower than the one obtained by learners with fewer hours of exposure (for example, Milton \& Meara, 1998; Takala, 1985). However, we could also add that the scores obtained by our sample of CLIL students are close to the scores obtained by 7 th grade/1st secondary education students in a quite similar context (Terrazas Gallego \& Agustín Llach, 2009). These students were exposed to the foreign language during 734 hours of instruction, and they obtained a mean word estimate of 817 words. With regards to the poor results obtained by this group of learners, Canga Alonso (2013) provides an explanation for similar results in a study of which our sample is a part. This author points to the need for examining the type of vocabulary input included in textbooks together with the number of occurrences of the words. Further studies should ascertain whether the poor results in the number of receptive words is somehow determined by the type of vocabulary-low frequency and more technical-to which these learners are exposed since, according to Dalton-Puffer (2011) or Heras and Lasagabaster (in press), CLIL contributes positively to the achievement of technical content-related vocabulary. To learn low frequency technical words through any content subject should not have a detrimental effect on knowing fewer high frequency words. In fact, previous studies have reported that CLIL fosters receptive vocabulary knowledge (for example, Jiménez Catalán, Ruiz de Zarobe, \& Cenoz 2006; Jiménez Catalán \& Ruiz de Zarobe, 2009).

The second research question addresses the differences in motivation levels of boys and girls. As in the case of receptive vocabulary knowledge, the male and female subjects of this study follow a similar pattern: first, there are more girls and boys who were highly motivated (level 3), followed by those who were 
motivated (level 2), and there were no students with low motivation; second, most students were more extrinsically than intrinsically motivated. Girls were more motivated than boys in general and in intrinsic motivation. Boys were more extrinsically motivated than girls. In other words, most boys and girls mainly thought that learning English as a foreign language was necessary, important, or useful, and boys in particular perceived the foreign language as more necessary, important, or useful than nice, attractive, pleasant, or interesting. Girls found English more attractive, pleasant, interesting, or nicer than boys did. However, this variation is not statistically significant. In another analysis, the correlation between intrinsic and extrinsic motivation in both groups has proven to be statistically significant, which means that learners who are intrinsically motivated are also extrinsically motivated, and vice versa. Finally, standard deviation is higher in the case of girls; boys behave more homogeneously in their motivational levels.

Overall, these findings point to there being no differences between boys and girls' motivation towards the foreign language. This absence of variation differs from the results of an important number of studies, which have reported a female advantage (for example, Sung \& Padilla 1998; Dörnyei \& Csizér, 2002; Mori and Gobel, 2006; Henry \& Apelgren, 2008; Dabbagh \& Khajehpour, 2011; Henry 2012). In addition, the fact that there are not statistically significant gender differences in the types of motivation levels stands in contrast to earlier findings, (for example, Dörnyei \& Clement, 2001; Dörnyei \& Csizér, 2002; Dörnyei, Csizér \& Németh, 2006), which concluded that girls obtain higher levels of both types of motivation. The present study's results are, however, in agreement with the research conducted by Azarnoosh and Birjandi (2012), who observed no differences in the attitude of males and females junior high school students.

The findings of the current study are likewise in line with recent research on CLIL, motivation, and gender variation, which found that CLIL has some waning effect on gender variation in language achievement, favouring males' achievement and motivation (Baker \& MacIntyre, 2000; Merisuo-Sorm, 2007). Although, the findings are at the same time against the idea noted by Lasagabaster and Sierra (2009), who explain that in weaker versions of CLIL this waning effect is cancelled out and a females' superiority is still present. In the context of the present study, a weak model of CLIL was implemented. 
The third question of this study is whether there were any connections between males and females' motivation and their receptive vocabulary size. A statistically significant relationship was obtained only in the case of males' vocabulary size and its connection with intrinsic and general motivation. This suggests that males' perception of English as nice, attractive, pleasant, or interesting is having some effect on the number of words they know receptively or that, due to the bidirectional interaction between motivation and language achievement, males' results in the $2 \mathrm{~K}$ VLT are also affecting their motivation levels. External factors are not identified as driving forces behind language achievement for any gender. The fact that intrinsic motivation is significantly connected to vocabulary results in this study supports the findings of previous studies, such as those of Bernaus and Gardner (2008) and Yu and Watkins (2008), which found that this type of motivation is a better predictor of language results than extrinsic motivation, as internal desires can lead students more strongly than external factors towards the completion of a particular task. This idea makes particular sense in the case of primary education students, who seem not very likely to perceive the practical purpose of learning a foreign language. However, research on these issues by Juriševič and Pižorn (2013, p. 191-192) concluded that external motivations are age- and context-dependent, as children also reported a desire to learn a foreign language to understand, for example, cartoons and other types of texts and materials.

Finally, as addressed in the review of the literature, the issue of the relationship between motivation and the productive-receptive types of vocabulary acquisition should be granted special attention here. Following Nation (2001, p. 28), in his illustration of the productive task, the sense of wanting to convey a message is a more demanding task than understanding words. Maybe this idea could explain the overall lack of statistically significant connections between motivation and the results in the VLT. A research study comparing motivation levels and achievement in receptive and productive vocabulary tasks would help clarify this issue.

\section{Conclusion}

The main results of this investigation show that (1) there are no statistically significant differences in the number of EFL words that boys and girls know of 
the 2,000-word frequency-band from the receptive version of the Vocabulary Levels Test (2K VLT), (2) no gender-based variation is identified in different types of motivation towards English as a Foreign Language, and (3) only the relationship between boys' intrinsic motivation towards EFL and the number of words they know receptively is statistically significant. Despite its exploratory nature, this study offers some insights into males and females' receptive vocabulary and motivation patterns. The lack of substantial gender-variation on both issues could be the resulting effect of CLIL, as reported in the literature.

However, with a small sample size, caution must be applied. Indeed, the sample size is one of the major limitations of this study. Perhaps a study conducted with a larger sample of students could help explain the connection between intrinsic motivation and vocabulary achievement in the case of boys. Another limitation is that the present study cannot explain whether CLIL is the only cause for the findings in motivation and vocabulary achievement, as the way that CLIL as carried out in the day-by-day classes has not been considered. Therefore, it is recommended that further research be undertaken in these areas at least in two ways: first, it seems advisable to conduct a longitudinal study in order to investigate the evolution of boys and girls' results in the two variables at stake here; and second, a comparative study on the results of this group of CLIL students and another group of non-CLIL students of the same age, if possible, could be of great help in explaining the role of CLIL in the findings. Another important caveat is to be noted regarding the type of task or test used to assess vocabulary knowledge and the scale used in measuring motivation. A replica study could be designed to examine whether these instruments might have had some effect on the results. For example, the 7-point rating scale that assesses motivation could be simplified with young children, as they may have difficulties in understanding the difference between a given value and the immediately preceding value.

Although the current study has only identified one statistically significant finding on the relationship between boys' intrinsic motivation and their achievement in receptive vocabulary, this finding may suggest the value of adopting a teaching approach that preserves the motivational and affective side of language learners. Moreover, if we interpret the lack of gender-variation in vocabulary size and motivation levels as CLIL's weakening gender effect, then teachers should consider CLIL as a valuable resource for coping with traditionally 
reported gender-based advantages and disadvantages in the foreign language classroom.

\section{REFERENCES}

Adolphs, S. \& Schmitt, N. (2004). Vocabulary coverage according to spoken discourse context. In P. Bogaard, P. and Laufer, B. (Eds.), Vocabulary in a second language (pp. 39-52). Amsterdam, the Netherlands: John Benjamins.

Agustín Llach, M. P. \& Terrazas Gallego, M. (2012). Vocabulary knowledge development and gender differences in a second language. ELIA: Estudios de la Lingüística Inglesa Aplicada, 12, 45-75. Retrieved from http://institucional.us.es/revistas/elia/12/art_3.pdf

Anglada, L. \& Banegas, D. (2012). Views on Motivation and Autonomy in ELT: Selected Papers from the XXXVII FAAPI Conference. San Martín de los Andes: APIZALS.

Azarnoosh, M., \& Birjandi P. (2012). Junior High School Students' L2 Motivational Self System: Any Gender Differences? World Applied Sciences fournal, 20(4), 577-584.

Baker, S. C. \& MacIntyre, P. D. (2000). The effects of gender and immersion on communication and second language orientations. Language Learning, 50, 311-347.

Bernaus, M. \& Gardner, R. C. (2008). Teacher Motivation Strategies, Student Perceptions, Student Motivation, and English Achievement. The Modern Language fournal, 92(3), 387-401.

Bruton, A. (2011). Is CLIL so beneficial or just selective? Re-evaluating some of the research. System, 39, 523-532.

Canga Alonso, A. (2013). The receptive vocabulary of Spanish 6th-grade primaryschool students in CLIL instruction: A preliminary study. Latin American Journal of Content and Language Integrated Learning, 6(2), 22-41. doi: $10.5294 / 3138$

Cenoz, J., Genesee, F., \& Gorter, D. (2013). Critical analysis of CLIL: Taking stock and looking forward. Applied Linguistics, 13, 1-21.

Council of Europe (2001). Common European framework of reference for languages: Learning, teaching, assessment. Cambridge, UK: Cambridge University Press. 
Coyle, D., Hood, P. \& Marsh, D. (2010). CLIL: Content and language integrated learning. Cambridge, UK: Cambridge University Press.

Csizér, K. \& Dörnyei, Z. (2005). The internal structure of language learning motivation and its relationship with language choice and learning effort. Modern Language fournal, 89, 19-36.

Dabbagh S. \& Khajehpour, M. (2011). Attitudes and motivation in learning English as second language in high school students. Procedia - Social and Behavioral Science, 15, 1209-1213.

Dalton-Puffer C., Nikula, T. \& Smit, U. (Eds.). (2010). Language use and language learning in CLIL classrooms. Amsterdam, the Netherlands: John Benjamins.

Dalton-Puffer, C. (2011). Content-and-language integrated learning: From practice to principles? Annual Review of Applied Linguistics, 31, 182-204.

Dalton-Puffer, C. \& Smit, U. (Eds.). (2007). Empirical perspectives on CLIL classroom discourse. Frankfurt, Germany: Peter Lang.

Deci, E. L. \& Ryan, R. M. (1985). Intrinsic motivation and self-determination in human behavior. New York, NY: Plenum Publishing.

Doiz, A., Lasagabaster, D. \& Sierra, J. M. (in press). CLIL and motivation: the effect of individual and contextual variables. Language Learning fournal.

Dörnyei, Z. (2005). The psychology of the language learner: Individual differences in second language acquisition. Mahwah, NJ: Lawrence Erlbaum.

Dörnyei, Z. (2009). The L2 motivational self system. In Z. Dörnyei \& E. Ushioda (Eds.). Motivation, language identity and the L2 self (pp. 92-142). Bristol, UK: Multilingual Matters.

Dörnyei, Z. \& Clement, R. (2001). Motivational characteristics of learning different target languages: results of a nationwide survey. In Z. Dörnyei \& R. Schmidt (Eds.), Motivation and second language acquisition (pp. 399-432). University of Hawai'I, Second Language Teaching and Curriculum Center, Honololu, HI.

Dörnyei, Z. \& Csizér, K. (2002). Some dynamics of language attitudes and motivation: results of a longitudinal nationwide survey. Applied Linguistics, 23, 421-462.

Dörnyei, Z. \& Ushioda, E. (Eds.) (2009). Motivation, language identity and the L2 self. Bristol, UK: Multilingual Matters. 
Dörnyei, Z., Csizér, K., \& Németh, N. (2006). Motivation, language attitudes and globalisation: A Hungarian perspective. Clevedon, UK: Multilingual Matters.

Fan, M. (2000). How big is the gap and how to narrow it? An investigation into the active and passive vocabulary knowledge of L2 learners. RELC fournal, 31, 105-119.

Fernández-Fontecha, A. (2010a). First steps of CLIL in a Spanish monolingual community: The case of La Rioja. In Y. Ruiz de Zarobe \& D. Lasagabaster, (Ed.), CLIL in Spain: Implementation, results and teacher training (pp. 79-94). Newcastle, UK: Cambridge Scholars Publishers.

Fernández-Fontecha, A. (2010b). Gender and motivation in EFL vocabulary production. In R. M. Jiménez Catalán (Ed.), Gender perspectives on vocabulary in foreign and second languages (pp. 93-116). London, UK: Palgrave Macmillan.

Fortanet-Gómez, I. (2013). CLIL in higher education: Towards a multilingual language policy. Bristol, UK: Multilingual Matters.

Gabryś-Barker, D. \& Bielska, J. (2013). The affective dimension in second language acquisition. Bristol, UK: Multilingual Matters.

Gardner, R. C. \& Lambert, W. E. (1972). Attitudes and motivation in second language learning. Rowley, MA: Newbury.

Golberg, H., Paradis, J., \& Crago, M. (2008). Lexical acquisition over time in minority first language children learning English as a second language. Applied Psycholinguistics, 29, 41-65.

Henry, A. (2012). Gender differences in compulsory school pupils' L2 selfconcepts: A longitudinal study. System, 37(2), 177-193.

Henry, A. \& Apelgren, B. A. (2008). Young learners and multilingualism: A study of learner attitudes before and after the introduction of a second foreign language to the curriculum. System, 36(4), 607-623.

Heras, A. \& Lasagabaster, D. (in press). The impact of CLIL on affective factors and vocabulary learning. Language Teaching Research.

Huang, K. (2011). Motivating lessons: A classroom-oriented investigation of the effects of content-based instruction on EFL young learners' motivated behaviours and classroom verbal interaction. System, 39(2), 186-201. 
Huang, S., Eslami, Z. R., \& Wilson, V. (2012). The effects of task-involvement load on 12 incidental vocabulary learning: A meta-analytic study. Modern Language fournal, 96(4), 544-557.

Jiménez Catalán, R. M., \& Ruiz de Zarobe, Y. (2009). The receptive vocabulary of EFL learners in two instructional contexts: CLIL versus non-CLIL. In R. M. Jiménez Catalán and Y. Ruiz de Zarobe (Eds.), Content and language integrated learning: Evidence from research in Europe (pp. 81-92). Bristol, UK: Multilingual Matters.

Jiménez Catalán, R. M., (Ed.). (2010). Gender perspectives on vocabulary in foreign and second language. Basingstoke, UK: Palgrave Macmillan.

Jiménez Catalán, R. M., Ruiz de Zarobe, Y., \& Cenoz, J. (2006). Vocabulary profiles in English as a subject and as a vehicular language. VIEWZ, 15(3), 23-27.

Juriševič, M. \& Pižorn, K. (2013). Young Foreign Language Learners' Motivation A Slovenian Experience. Porta Linguarum, 19, 179-198.

Kim, Y. (2008). The role of task-induced involvement and learner proficiency in L2 vocabulary acquisition. Language Learning, 58(2), 285-325.

Lasagabaster, D. (2003). Trilingüismo en la enseñanza: Actitudes hacia la lengua minoritaria, la mayoritaria y la extranjera. Lleida, Spain: Milenio Educación. Lasagabaster, D. (2011). English achievement and student motivation in CLIL and EFL settings. Innovation in Language Learning and Teaching, 5, 3-18.

Lasagabaster, D. \& Sierra, J. M. (2009). Language attitudes in CLIL and traditional EFL classes. International CLIL Research fournal, 1(2). Retrieved from http://www.icrj.eu/12/article1.html

Laufer, B. \& Hulstijn, J. (2001). Incidental vocabulary acquisition in a second language: the construct of task-induced involvement. Applied Linguistics, 22, 1-26.

Laufer, B. \& Paribakht, T. S. (1998). The relationship between passive and active vocabularies: Effects of language learning context. Language Learning, 48, 365-391.

Llinares, A., Whittaker, R., \& Morton, T. (2012). The roles of language in CLIL. Cambridge, UK: Cambridge University Press.

López-Mezquita, M. T. (2005). La evaluación de la competencia léxica: Tests de vocabulario: Su fiabilidad y validez (Unpublished doctoral dissertation). Universidad de Granada, Granada, Spain. 
Masgoret, A-M. \& Gardner, R. C. (2003). Attitudes, motivation, and second language learning: Meta-analyses of studies by Gardner and associates. In Z. Dörnyei (Ed.), Attitudes, orientations and motivations in language learning (pp. 167-210). Oxford, UK: Blackwell.

Mearns, T. L. (2012). Using CLIL to enhance pupils' experience of learning and raise attainment in German and health education: A teacher research project. Language Learning fournal, 40(2), 175-192.

Mehisto, P., Marsh, D., \& Frigols, M. J. (2008). Uncovering CLIL: Content and language integrated learning in bilingual and multilingual education. Oxford, UK: Macmillan.

Merisuo-Storm, T. (2007) Pupils' attitudes towards foreign-language learning and the development of literacy skills in bilingual education. Teaching and Teacher Education, 23, 226-235.

Milton, J. \& Meara, P. (1998). Are the British really bad at learning foreign languages? Language Learning fournal, 18, 68-76.

Mokhtar, A. A., Rawian, R. M., Yahaya, M. F., Abdullah, A., Mansor, M., Osman, M. I., ... Mohamed, A. R. (2010). Vocabulary knowledge of adult ESL learners. English Language Teaching, 3(1), 71-80. doi:10.5539/elt.v3n1p71

Mori, S. \& Gobel, P. (2006). Motivation and gender in the Japanese EFL classroom. System, 34(2), 194-210.

Murtagh, L. (2007). Out-of-school use of Irish, motivation to learn the language and proficiency in immersion and subject-only post-primary programmes. International fournal of Bilingualism and Bilingual Education, 10(4), 428-453.

Nation, P. (2001). Learning vocabulary in another language. Cambridge, UK: Cambridge University Press.

Nation, P. (2006). How large a vocabulary is needed for reading and listening? The Canadian Modern Language Review/La revue canadienne des langues vivantes, 63, 59-81.

Noels, K. A., Pelletier, L. G., Clément, R., \& Vallerand, R. J. (2000). Why are you learning a second language? Motivational orientations and self-determination theory. Language Learning, 50, 57-85.

Qian, D. (2002). Investigating the relationship between vocabulary knowledge and academic reading performance: An assessment perspective. Language Learning, 52(3), 513-36. 
Ruiz de Zarobe, Y., \& Jiménez Catalán, R. M. (Eds.) (2010). Content and language integrated learning: Evidence from research in Europe. Bristol, UK: Multilingual Matters.

Schmidt, R. \& Watanabe, Y. (2001). Motivation, strategy use, and pedagogical preferences in foreign language learning. In Z. Dörnyei \& R. Schmidt (Eds.), Motivation and second language acquisition (Technical Report \#23) (pp. 313-359). Honolulu, HI: University of Hawai'i, Second Language Teaching and Curriculum Center.

Schmitt, N. (2000). Vocabulary acquisition. In N. Schmitt (Ed.), Vocabulary in language teaching (pp. 116-141). Cambridge, UK: Cambridge Language Education.

Seikkula-Leino, J. (2007). CLIL learning: achievement levels and affective factors. Language and Education, 21(4), 328-341.

Sung, H. \& Padilla, A. M. (1998). Student motivation, parental attitudes, and involvement in the learning of Asian languages in elementary and secondary schools. The Modern Language fournal, 82, 205-216.

Takala, S. (1985). Estimating students' vocabulary sizes in foreign language teaching. Practice and problems in language testing. In V. Kohonen, H. van Essen, \& C. Klein-Braley (Eds.), Practice and problems in language testing (pp. 157-65). Tampere, Finland: Finnish Association for Applied Linguistics.

Terrazas Gallego, M. \& Agustín Llach, M. P. (2009). Exploring the increase of receptive vocabulary knowledge in the foreign language: A longitudinal study. International fournal of English Studies, 9(1), 113-133. Retrieved from http://revistas.um.es/ijes/article/viewFile/90681/87481

Tseng, W-T. \& Schmitt, N. (2008). Toward a model of motivated vocabulary learning: A structural equation modeling approach. Language Learning, 58(2), 357-400.

Xanthou, M. (2010). Current trends in L2 vocabulary learning and instruction. Is CLIL the right approach? In A. Psaltou-Joycey \& M. Mattheoudakis (Eds.), Advances in research on language acquisition and teaching: Selected papers (pp. 459-471). Thessaloniki, Greece: Greek Applied Linguistics Association (GALA).

Yu, B., \& Watkins, D. A. (2008). Motivational and cultural correlates of second language acquisition: an investigation of international students in the 
universities of the People's Republic of China. Australian Review of Applied Linguistics, 31(2), 17.1-17.22.

Zheng, Y. (2012). Exploring long-term productive vocabulary development in an EFL context: The role of motivation. System, 40, 104-119.

\section{APPENDIX 1: 2K VLT}

This appendix presents the 2,000-word frequency-band from the receptive version of the Vocabulary Levels Test (2K VLT) (Schmitt, Schmitt, \& Clapham 2001).

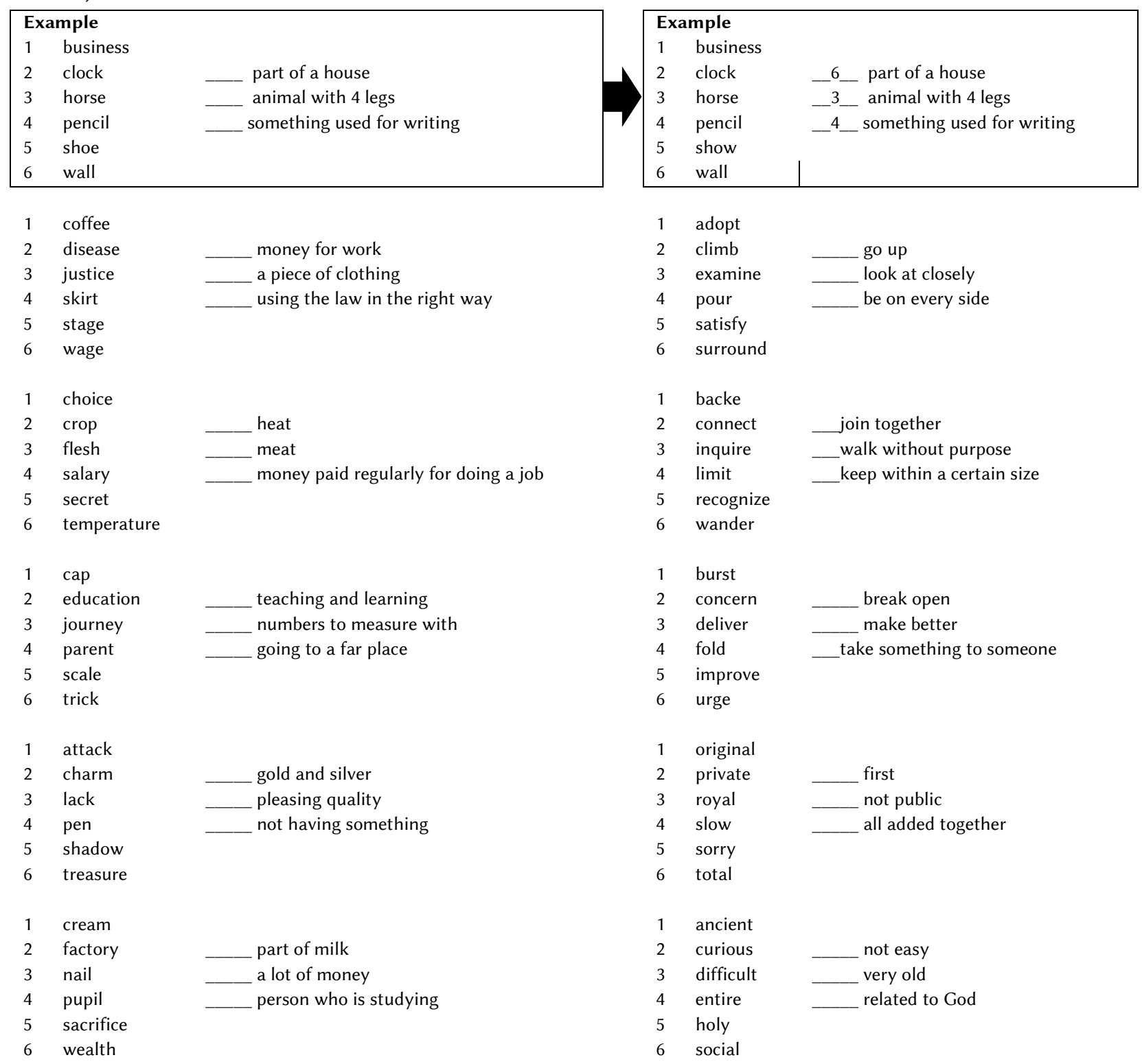




\section{APPENDIX 2: LIKERT ADAPTED FROM GARDNER'S (1985) A/MTB SCALE}

Table 7. Likert adapted from Gardner's (1985) A/MTB scale.

\begin{tabular}{|l|l|l|l|l|l|l|l|l|}
\hline Necesario & & & & & & & & Innecesario \\
\hline Feo & & & & & & & & Bonito \\
\hline Difícil & & & & & & & & Fácil \\
\hline Atractivo & & & & & & & & No atractivo \\
\hline Agradable & & & & & & & & Desagradable \\
\hline Poco importante & & & & & & & & Importante \\
\hline Inútil & & & & & & & & Útil \\
\hline Interesante & & & & & & & & Aburrido \\
\hline
\end{tabular}

\section{BIODATA}

Almudena FERNÁNDEZ-FONTECHA is a lecturer at the University of La Rioja (Spain). She is a member of the Applied Linguistics Group at the UR (GLAUR). Her main research interests include L2 vocabulary learning, content and language integrated learning (CLIL), information and communication technologies (ICTs), task-based language teaching (TBLT), and individual factors such as creativity and motivation. 